\title{
DEBATING FEMALE MUSICAL PROFESSIONALISM AND ARTISTRY IN THE BRITISH PRESS, C.1820-1850*
}

\author{
DAVID KENNERLEY
}

Worcester College, Oxford

\begin{abstract}
The entrance of women into the male-dominated spheres of the professions and the arts has been a major theme of women's and gender history in nineteenth-century Britain. In general, historians have located this development primarily in the second half of the century and depicted it as an important corollary to the political aims of the wider women's movement. In contrast, this article contends that an overlooked earlier context for the formation and emergence of ideas of female professionalism and artistry were the debates surrounding female singers in the press between c.1820 and 1850. In this era, writers in newly-emerging specialist music periodicals increasingly advocated a view of female singers as both professionals and artists. Such views did not dominate discourse, however. There remained a great deal of ambivalence even in specialist publications about just how far female singers should pursue the lifestyle of the professional artist, while in the mainstream press very different attitudes towards female singers prevailed. Although female musical professionalism and artistry therefore remained contested concepts, this article highlights the significance of these debates about female singers as an important source for the new ideas about women's professional and artistic work emerging in nineteenth-century British society.
\end{abstract}

\section{I}

Two themes have been prominent in historical scholarship on the status of musicians in the late eighteenth and nineteenth centuries: the gradual emergence of the musician as an expressive 'artist' serving an urban music market, rather than aristocratic, state, or ecclesiastical patrons; ${ }^{1}$ and the increasingly strong desire among musicians for 'professional' status equivalent to that of doctors or lawyers, even if such hopes were far from fully realized. ${ }^{2}$ A quarter-century ago, it was frequently argued that these were overwhelmingly negative developments for women working in musical life. It seemed clear to many scholars that contemporaries strongly associated artistic 'genius' with masculine intellect, ${ }^{3}$ while they considered the demands of professional work to be antithetical to the proper pursuit of 
feminine domesticity. ${ }^{4}$ Over the last twenty years, however, a more balanced picture of the impact of these developments has emerged. While noting the pronounced opposition to women taking up professional work, Penelope Corfield has suggested that the meritocratic ethos of professionalism also laid its gender-biases open to challenge by women. ${ }^{5}$ Studies of female teachers, writers, and painters have explored the extent to which women could adopt and adapt the rhetoric of professionalism to bolster their own position in public life. ${ }^{6}$ Others have examined how the prejudice against women's artistry and creativity was at least brought into question (if by no means dismantled entirely) by events such as the unintentional admittance of Laura Herford to the Royal Academy schools in $1860,{ }^{7}$ or the defence of female composers mounted by Stephen S. Stratton in a paper delivered before the Musical Association in $1883 .{ }^{8}$

Most of this research has focused on developments in the second half of the nineteenth century and has linked the expansion of women's professional and artistic activities, through such figures as Barbara Leigh Smith Bodichon, to female political activism, campaigns for female employment, and the emergence of the organized women's movement from the 1850 s onwards, ${ }^{9}$ as well as to the debates about women's work and the 'New Woman' of the 1890s. ${ }^{10}$ Meanwhile, any growth in opportunities for women working in the arts before mid-century has been attributed by Ellen Jordan to the influence of the bluestockings and evangelical religion. If women were the moral and spiritual equals of men, they must receive an intellectual education capable of equipping them to exercise moral autonomy, which, Jordan argues, included education in the arts, offering women higher standards of training in music or painting than previously available. These skills were still primarily intended for use in the home, but could also, if need arose, be used to earn a living by teaching, or even practising, their art. ${ }^{11}$ 
The purpose of this article is to suggest that some of the key ideas about female professionalism and artistry that animated the early women's movement during the 1850s and after were not entirely new, but can in fact be traced within debates surrounding female singers between $c .1820$ and 1850. It builds on the work of Jane Rendall and Kathryn Gleadle by offering further insights into the intellectual and cultural context of the 1820s, '30s and '40s out of which the organized women's movement emerged. ${ }^{12}$ In contrast to the views of Jordan, it argues that these early justifications of female artistic work were primarily derived not from evangelical religion, but from a rather more secular discourse of professionalism and Romantic ideals of the 'artist', which were applied unusually early to the situation of professional female singers for two main reasons. Firstly, the female singing voice is a gender-specific talent. In almost all other forms of female professionalism and artistic endeavour, including women's instrumental musical performance, much effort had to be spent in persuading society that women were justified in taking a role that could be done by men, often by arguing that because of its links to domestic life (as in education and nursing) it was particularly suited to female abilities. ${ }^{13}$ Evidently, there was no need for this in the case of female singers. If people wished to enjoy the female singing voice in professional music-making, they had to tolerate at least, if not embrace, some form of 'professional' role for female singers. Secondly, the professional role of the female singer proved more difficult to reconcile with contemporary notions of domesticity. Whereas women's work as authors or painters could be justified (at least by more apologetic advocates such as Margaret Oliphant) by arguing that it took place within the home around their domestic duties, ${ }^{14}$ this was manifestly not the case with female professional singing, which necessitated appearance at public concerts or theatres. The only comparable forms of women's professional artistic 
activity were acting and dancing, where significant new lines of debate were also emerging, particularly in relation to the career of Sarah Siddons. ${ }^{15}$

The representation of female singers is therefore worthy of closer investigation, but in order to render visible the ways in which they might have been thought of as professional artists, we need to adopt a different theoretical approach to professionalization as a historical process. Previous studies, such as that of Deborah Rohr, have argued that musicians as a group failed to develop the self-regulation of training, licensing, examination, and conditions of work achieved by archetypal professional groups such as doctors or lawyers. Adopting this 'ideal-type' model, however, in which all aspiring professional groups are measured against criteria derived from the late nineteenth-century and twentieth-century medical or legal profession, risks obscuring alternative forms of professional identity and leads Rohr to the conclusion that the vast majority of male and female musicians did not achieve professional status. ${ }^{16}$

An alternative approach has been offered by Christina de Bellaigue who, building on more recent sociological theories of professionalization, calls for 'an analysis that is more alert to the processes by which certain occupations identified themselves as professional' and suggests that 'professionalization should be seen as a historically situated project rather than a fixed model' ${ }^{17}$ As de Bellaigue argues, this approach is much more likely to expose the extent of female professionalism in the early nineteenth century, given that women were generally even less likely than their male counterparts to be accepted into any formal training and licensing structures that existed for their particular occupation. While Rohr is right to emphasize the considerable social prejudice and obstacles in the way of the unequivocal recognition of musicians' professional status, it is nevertheless vital to consider the ways in which musicians adopted a form of 'professional' identity, even if this was 
highly specific to their circumstances and not accepted by the rest of society as equivalent to that of doctors or lawyers. As the following analysis will suggest, female musicians' professional identity, at least as represented in specialist music periodicals, was most frequently defined against an idea of musical amateurism, rather than with reference to professional accreditation, licensing, or examination. Through seeking to identify those who disputed and undermined, as well as those who advocated, female musical professionalism, this article seeks to recover the complex intersection between a growing culture of professionalism and prevailing ideas about gender within the British musical world in the first half of the nineteenth century.

The focus of this article is on comparing and contrasting representations of female singers in the early nineteenth-century musical press. This is, of course, only one window onto a complex process of change; the actions of the singers themselves and the audiences who listened to them played a vital part in provoking and consolidating these new ideas. Indeed, the admittance of women as pupils and their work as tutors at the Royal Academy of Music from its foundation in $1822,{ }^{18}$ or the establishment in 1839 by leading women in the profession of a Society of Female Musicians to offer pensions to retired or incapacitated members, ${ }^{19}$ demonstrate the determination of some of these women to bring about change in their working conditions. Recovering the agency of singers and audiences, through investigating their letters, diaries, and other personal documents, is an important part of explaining these developments. ${ }^{20}$ However, concentrating in detail on the musical press permits a deeper understanding of not just how representations of female singers were changing, but also of the development of professional music criticism. It is no coincidence that these changing attitudes towards female musical professionalism are to be found primarily in the pages of a new type of specialist music periodical which appeared for the 
first time in the late 1810s. As the following analysis will show, one of the ways in which the newly-emerging form of professional music criticism such periodicals contained distinguished itself from other styles of contemporary commentary on music was through its attitude towards women in the music profession. It is in order to demonstrate how changing attitudes towards female singers interlinked with the rise of new styles of music criticism that this article focuses exclusively upon debates within the press.

\section{II}

The early nineteenth century was a period of rapid expansion, innovation, and diversification in the musical press. Eighteenth-century music periodicals had been mostly devoted to disseminating new music for amateur performance. ${ }^{21}$ Their nineteenth-century counterparts, however, such as the Quarterly Musical Magazine and Review (1818-30, hereafter QMMR), the Harmonicon (1823-33), the Musical World (1836-91) and the Musical Examiner (1842-4), substantially, or entirely, consisted of letterpress articles on a much wider range of topics, including extensive discussion of the status of the music profession, musical training, different styles of composition and performance, the development of musical taste, correspondence from readers, and reviews of performers and composers. ${ }^{22}$ Although the balance varied between periodicals, they were designed for a mixed readership of musical professionals and keen amateurs eager for news and reviews of events in national and international musical life, rather than those simply seeking to collect new music. ${ }^{23}$ Their emergence reflects both the new ways in which amateurs and professionals, performers and audiences, interacted as part of an increasingly cosmopolitan musical culture as well as the coalescence of a body of opinion seeking to persuade the rest of society that music was a serious, intellectual, and respectable activity. 
These 'specialist' periodicals, however, were not the only forum in which discussion of female musicians appeared. More general interest periodicals and newspapers remained, in terms of volume and readership, the most common venue for writing about female performers. While the Harmonicon struggled to reach a monthly circulation of 1,000 , the Musical World, which claimed a weekly figure of 5,000 by the mid-1840s, may just have matched a periodical such as the Examiner (c.5,100 weekly), but was far outstripped by daily papers such as the Morning Chronicle $(c .5,000)$ or The Times $(c .26,000) .{ }^{24}$ Even allowing for the circulation of single copies of specialist periodicals among social networks, the 'nonspecialist' press undoubtedly shaped perceptions of the musical world among a far wider proportion of society on a more frequent, often daily, basis. Furthermore, it would be wrong to imply that the rise of the specialist press represented the only innovation; during this period, some of the major periodicals and newspapers began to carry regular columns devoted to reporting on musical events and, from the mid-1840s, employed professional music critics to write them..$^{25}$ As a result, there was significant cross-fertilisation and exchange between the specialist and non-specialist press; prominent writers from the music periodicals such Richard Mackenzie Bacon, William Ayrton, and James William Davison, editors of the QMMR, Harmonicon, and Musical World respectively, all contributed articles to general interest periodicals or wrote musical columns in national newspapers. ${ }^{26}$ Nevertheless, as we shall see, the more general readership of the non-specialist press meant that the critical priorities of most columnists in such publications were often quite different to those found in the specialist press. Consequently, drawing a distinction between 'specialist' and 'non-specialist' forms of musical commentary is a useful way of articulating the relationship between developments in print culture and the emergence of rival centres of 
gravity within the diverse contemporary debates on the musical world and female singers in particular.

One of the most distinctive features of the 'specialist' press was its extensive, determined advocacy of the notion of the musician as both a 'professional' and an 'artist'. Long articles were devoted to describing and debating the rigorous, prolonged training and hard work required of the aspiring professional and the necessity for musicians to cultivate the passionate emotional temperament of the artist. ${ }^{27}$ Moreover, they paid particular attention to distinguishing the professional from the amateur musician. 'Amateurs are perfectly unconscious of the time, labour, fatigue, and perseverance it costs to obtain even the rudiments of skilful professional execution' ${ }^{28}$ declared one correspondent of the $Q M M R$, while another argued: 'To sing finely is the labour of a life... The [professional] pursues the art regularly, systematically, and sedulously, under great advantages; the [amateur] very rarely indeed follows it either with constancy, method or earnestness, and under every disadvantage.' ${ }^{29}$ This stance was reinforced by articles, with titles such as 'On the differences in the singing of professionals and amateurs', which took each aspect of vocal performance in turn, and detailed (in almost every case) the impossibility of amateurs performing to professional standards. ${ }^{30}$ The sharpening of the amateur/professional divide in the rhetoric of these periodicals was at the core of the articulation of the professional identity of musicians in this era.

This had significant ramifications for professional female musicians. Taking a lead from Michèle Cohen's study of the changing languages used to describe girls' education, to grasp fully the effects this had upon female singers we need to be very attentive to how the meanings attached to both amateur and professional female musical performance by the writers in the music periodicals differed from other types of contemporary writing on 
female musical performance. ${ }^{31}$ As Cohen, Richard Leppert, and others note, amateur female musical performance was intricately bound up with certain notions of virtuous feminine behaviour. ${ }^{32}$ Discussions of female musical performance in conduct literature emphasized the need for diffidence and modesty and condemned anything that might resemble exhibitionism or vanity. Hannah More (whose works were regularly reprinted in the early nineteenth century) argued that feminine accomplishments such as music were to be

exerted in the shade, to enliven retirement, to heighten the endearing pleasures of social intercourse, and to embellish the narrow but charming circle of family delights. To this amiable purpose, a truly good and well-educated young lady will dedicate her more elegant accomplishments, instead of exhibiting them to attract admiration. ${ }^{33}$

To use accomplishments for self-display and to attract attention was a degradation of true femininity. In another regularly republished work, Hester Chapone observed 'you may be sure vanity is the only motive' of those girls who let their accomplishments 'lie dormant, till the arrival of a stranger gives [them] spirit in the performance', ${ }^{34}$ while Erasmus Darwin warned against accomplishments which 'consist in an exhibition of the person' because they 'are liable to be attended with vanity, and to extinguish the blush of youthful timidity; which is in young ladies the most powerful of their exterior charms' ${ }^{\prime} 35$

The foundations laid by these often-reprinted late eighteenth-century works were developed further by the pre-eminent female conduct writer of the early Victorian era, Sarah Stickney Ellis. 'Surely [music] ought not to be cultivated as the medium of display', wrote Ellis, 'so much as the means of home enjoyment; not so much as a spell to charm the stranger... as a solace to those we love' ${ }^{36}$ Most importantly, Ellis expanded the implied 
criticism by More, Chapone and others of female self-display and competition, into a far more wide-ranging condemnation of all female 'ambition' for admiration beyond the domestic sphere. '[T]here sometimes exists in the female breast', warned Ellis, 'a passion of a deeper and still more dangerous nature... I mean the love of distinction. In man, this passion is ambition. In woman, it is a selfish desire to stand apart from the many; to be something of, and by, herself' ${ }^{37}$ If a woman wished to 'preserve her peace, her safe footing in society, her influence, and her unblemished purity, [she] must avoid remark as an individual, at least in public' ${ }^{38}$ Ellis concluded the section by quoting a passage from Maria Jane Jewsbury's morality novel, 'The History of an Enthusiast': 'What is fame to a woman, but a dazzling degradation... However much as an individual she may have gained in name, in rank, in fortune, she has suffered as a woman' ${ }^{39}$ In the eyes of instructors such as Ellis, women who chose to use their musical skills to further their professional ambitions, for public selfdisplay, and to compete with rivals for fame and admiration were irreconcilable with true femininity and morality. Conduct writers do not, of course, straightforwardly reflect the opinions or behaviour of their readers, or indeed wider society ${ }^{40}$ but they do offer an idea of the kind of pervasive rhetoric which contributed to the moral suspicions levelled against the female public performer and allow us to see in greater relief the significance of the new discourses emerging in the musical press. Moreover, this also suggests important reasons to question the link made by Ellen Jordan between the emphasis placed by More, Ellis, and others on improving women's moral and intellectual education and the increasing numbers of women working as professional artists and musicians. ${ }^{41}$ While writers like More and Ellis may well have done much to encourage a more serious, intellectual approach to the study of the arts by amateur young women, this clearly stopped a long way short of advocating women's professional artistic work. 
Writers in the specialist music press viewed female amateurs from an utterly different perspective. Whereas conduct writers condemned female amateurs if they showed too much ambition to be admired in public, writers in the music periodicals dismissed them for lacking the ambition to pursue the highest standards of musical art and the training and dedication necessary to produce it, having been tutored only for superficial display in drawing rooms to attract marriage partners. Such performances could never match the more serious and artistic musical performances of their professional female counterparts who, far from being condemned, were to be praised for their ambition to further the cause of Art and shine in public performance. Consequently, the performances of female amateurs were frequently mocked in the specialist press. Reflecting on the mediocre performance of two young ladies at a private concert at a nobleman's house in London in the 1820s, one correspondent of the $Q M M R$ explained their failings by pointing out that, far from being instructed for the purposes of artistic, skilful performance, 'both these young ladies had been trained for display'. Their motive for pursuing music, he wrote, was 'The charm which attends the exhibition of talent to a large circle, and (as connected with it) the effect such display may have upon the future fortunes of the musician', i.e. their marriage prospects. ${ }^{42}$ One satire likened amateur female singing to a competition of urchins at a country fair scrabbling to climb a greasy pole desperate to reach the bowl full of money at the top. There could be no artistic merit in such performances, the satirist asserts, when they are put to such purposes; all the connoisseur can do is try to stifle his laughter 'at every slip or failure in the greasy ascent'. ${ }^{\prime 3}$

Just as female amateurs were to be dismissed for their poor performance standards and lack of artistic skill, so professional female singers were to be praised for their technical 
training, professional skill, and expressive artistry. One review of Rosamunda Pisaroni, for instance, observed that:

The deportment of voice - the purity and uniformity of the tone - the noble simplicity of the declamation - the accurate articulation both of syllables and sounds - the gradual melting and assimilation of tone... the retention of legitimate and the rejection of meretricious ornament - and lastly, the power of bending all these elements to the changeful purposes of expression, declare at once the mind, the training, and the experience of the gifted artist. ${ }^{44}$

Similarly, early nineteenth-century reviewers subjected aspiring professional female singers to rigorous critique and condemned bad singing as professional and artistic failure, as in the following review of a young singer from 1839:

Miss Austin's voice is a high soprano of tolerable power, and moderate compass. The upper portion of the voice is decidedly the best, although some of the tones are shrill and harsh, which is the result of overstraining... The lower part of the voice is very poor, and the middle tones are feeble, and it is altogether deficient in expression and sweetness... The facility of her execution is considerable, but her enunciation is very indistinct; and as is the case with all voices overstrained, the lady frequently sings out of tune - SHARP. ${ }^{45}$

Using the same criteria, but in a more positive vein, one critic in the $Q M M R$ wrote of Miss Povey:

Her natural organ is fine, powerful and considerable, and she is proceeding soberly and by just degrees to excellence. Her tone is pure, rich, and sweet in its 
quality, and with as much brilliancy as consists with the fullness. Her compass is extensive, and the notes are equal and alike throughout - thus proving the judgement with which her voice has been formed... How far her imagination ranges, or how deeply imbued her mind may be with the poetry of art, a subordinate station in the theatre forbids her to disclose,

though the reviewer expressed a confident hope that future opportunities to display such talents would soon present themselves. ${ }^{46}$ In his eyes, her careful cultivation of her voice, a superlative technique and a clear potential to express the 'poetry of art' marked out Povey as a truly meritorious professional artist.

As the language of these and many other similar reviews demonstrates, these writers believed the ideal of the professional musical artist to be the goal to which these women should aspire and which, with the right training and talent, they were more than capable of achieving. ${ }^{47}$ They were also keen to advocate that society should adopt a more positive attitude towards such women, who should not be subject to moral stricture for their public role, but praised for their professional dedication and talent. 'We rejoice', wrote the editor of the Musical World in 1839,

to do justice to the immense talent which the fair community of this country are developing in every department of practical music. Of lady singers of singular merit and promise we have a perfect swarm. They are no longer to be viewed as flippant dolls, got up, as the phrase is, in a certain music lesson for concert-room exhibitions, but as serious artists, who enter with enthusiasm into all the deepest passion of music, and sympathize in even the remotest conceptions of the composer. ${ }^{48}$ 
Evidently, this editor believed that society's idea of the professional female singer needed to change. They were not poorly trained 'dolls', whose performances, like those of amateur female musicians, were mere 'exhibitions' of feminine prettiness and propriety, as much visual as aural, and approached with the same flippancy and superficiality. Rather, they were 'serious', professional 'artists', whose temperament, talent, and training allowed them to give deeply expressive, high quality, artistic performances. Moreover, there is no suggestion that the lifestyle of the professional artist might compromise the femininity or respectability of these women; they could and should, this editor implies, inhabit the role of professional musician just as appropriately and successfully as their male counterparts.

This Musical World editorial is a particularly striking and confident expression of the new attitudes towards female singers emerging in the specialist music periodicals in the first half of the nineteenth century. It represents a very important development in the history of female singers, signalling the emergence of a quite different understanding of the relationship between a female singer and her audience and the purpose and value of professional female music-making. However, looked at more closely, the picture is significantly more complicated than such triumphant comments might suggest. Firstly, this editor and his colleagues were seeking to change how their own work as critics was viewed; if singers were 'serious artists' rather than 'flippant dolls' then the work of critically evaluating them was likewise a serious, professional endeavour. Secondly, particularly when comparing representations of English and foreign female singers, it becomes clear that even in specialist periodicals tensions remained between ideas of respectable femininity and professional artistry. Thirdly, comparing attitudes towards the importance of the body, physical attractiveness, and sexuality in female musical performance in the specialist and general press reveals the limits of the influence of these new ideas about female professional 
musicians. The new voices emerging in the specialist music periodicals were but one strand in a complex, multi-faceted debate.

\section{III}

Discussions of music, gender, and nationality reveal with particular clarity the persistent tensions between femininity and professional artistry in the minds of writers in the specialist music periodicals. For most of these individuals, possession of an artistic temperament was the fundamental basis for excellent musical performance. As the man of letters and music journalist Egerton Webbe declared in the Musical World in 1837: 'one of the very foremost propositions respecting performance [is] that it must proceed of feeling, or is nought'. ${ }^{49}$ Because of this emphasis on inner disposition and emotional self-expression, perceived differences in national emotional temperaments played an increasingly significant role in shaping responses to and writings about musical performances. Although the contrasts between different nationalities in this regard applied to all musicians, it was at its most intense in relation to female singers. This was because the powerful emotional and dramatic self-expression required of the 'artist', especially in operatic performance, was felt by some writers to sit uncomfortably alongside the emotional restraint associated with respectable femininity in wider English society. Deborah Rohr has given an excellent overview of some of these issues, especially as they relate to the notions of 'effeminate' Italian and 'manly' English musical styles; ${ }^{50}$ the present analysis seeks to explore in more depth how these questions affected female singers specifically and how they developed across the period in question.

During the 1810s and 1820s, critical reviews of the performances of female singers were increasingly phrased in terms of a dichotomy between the 'chaste' style and 'coldness' 
of the English and the 'impassioned', 'vehement', or 'dramatic' style of the Italians, attributed to differences in 'nature' or 'temperament'. ${ }^{51}$ 'The very essence of Italian singing', wrote one correspondent in the $Q M M R$, is

that it is dramatic... they aim at seeming to be (as nearly as possible) the person they suppose to be singing, and to identify in themselves all the passions by which that individual is represented as being influenced. To this grand end they are incited by their naturally more ardent temperament... They are not in the least shocked by what the English would deem extravagance..$^{52}$

Those who were swept away by the dramatic force of Italian performers often found English female singers lacking in fervour. ${ }^{53}$ One review of the English soprano Catherine Stephens read: 'we have never perhaps heard a singer who moved the high affections less... we doubt whether the warmth of feeling and fertility of imagination which are indispensable to perfect dramatic performance are inherent in MISS STEPHENS's nature'. ${ }^{54}$ This was a common problem among English female singers, the reviewer observed, stemming from 'a coldness of conception which derogates from the effect of all they do'.$^{55}$

At the same time, other English critics and audiences felt that the exuberant emotional temperament of the Italians, despite giving their singing its seductive power, could all too easily lead them into 'excess' and 'extravagance', with shocking, disconcerting, or implausible results. ${ }^{56}$ Consequently, some preferred the more restrained style of English female singers. 'MISS TRAVIS', read one review in the QMMR,

indicates rather the decent and becoming rigour of feminine modesty in the picturings of her imagination... than any degree of heated, enthusiastic, or 
theatrical CONCEPTION... Her singing is... plain, sensible, and that of a gentlewoman... there is always to be commended a purity and sobriety, a graceful and dignified reserve, which is at all times grateful to the national estimate of character and manners. ${ }^{57}$

Quite which style was favoured depended in part on the genre of performance and the personal taste of the reviewer; the demands placed upon the emotional expression of the performer varied widely between the passions of the opera and the pious restraint of an oratorio. ${ }^{58}$ Nevertheless, the striking references to 'feminine modesty', the singing of a 'gentlewoman' and the 'graceful and dignified reserve... grateful to the national estimate of character and manners' in this review of Travis betray the fact that demonstrations of emotional restraint in female musical performance possessed a particular significance to English observers. 'In this, indeed, our singers are truly national', wrote one reviewer in the $Q M M R$, 'their reserve accords with English notions of feminine manners, and we would not, for any consideration, trespass upon an opinion which is perhaps one of the great conservators of our morals and our happiness'.59 Though English male musicians' performances, conforming to the national stereotype, might be similarly described as 'chaste', such comments make it unmistakably clear that maintaining this emotional reserve had important and specific connotations for female musicians.

Time and again, therefore, critics expressed concern that if English female singers displayed a similar emotional 'extravagance' to their Italian counterparts, they were at risk of transgressing English standards of feminine propriety regarding emotional expression. The English, one correspondent of the QMMR explained, 
are shocked at dramatic vehemence; it appears to us somewhat allied to what is coarse and unbecoming, particularly in our female singers. Our vocalists seek only to move or agitate the mind gently... which... sets limitations upon manner, that the Italians neither feel to be necessary nor care to observe. They esteem us cold and spiritless; - we esteem them violent and given to excess. ${ }^{60}$

If English female musical artistry was to be compatible with conceptions of feminine delicacy and avoid what was 'coarse and unbecoming', this critic suggests, it had to be a very different kind of artistic endeavour to the 'dramatic vehemence' favoured by the Italians. Some believed that the concern of English female singers to accord with English notions of feminine emotional restraint prevented them from achieving compelling and moving artistic performances altogether:

An Italian woman never employs a moment in considering what her auditors will think of her. She delivers herself up wholly, solely, and entirely to the rising emotions... On the contrary, I am very apt to believe that the first consideration of an English woman is the reserve which her auditors may think necessary to the delicacy of the English character... She dares not indulge in "the noble rage" which art demands in order to enable us to move the affections of others. ${ }^{61}$

This correspondent's impatience with those who 'may think' reserve necessary for feminine delicacy at the expense of the 'demands' of art is palpable, implying that some in British musical life wished that English female singers might unleash their emotions and become true artists like their Italian counterparts. Other auditors clearly felt quite differently, however, and it was their anxiety about the dangers of specifically female 
emotional expression through art that had, in his opinion, produced the 'coldness', 'reserve' and 'modesty' traceable in the performances of English female singers as a form of defensive response. According to these critics, it was not just that English female singers had been trained in the restrained conventions of oratorio rather than the dramatic passions of the opera, nor was it simply that a national emotional tendency applicable to both genders equally limited their ability to unlock their own emotions. Rather, these factors were combined with a powerful English sense of the particular importance of emotional restraint to feminine propriety in a way which placed limits upon the notion of English female artistry.

As a result, the audible emotional restraint and 'feminine modesty' in the performances of English singers such as Catherine Stephens or Deborah Travis was interpreted as signalling their conformity with notions of feminine propriety. One critic even went so far as to compare the English and Italian styles of performance to the codes of emotional restraint necessary for happiness in domestic life: 'To the Italians belong passion, force, transition, variety, and general splendour. To the English, sensibility tempered by an invariable sense of propriety, purity, delicacy, and polish... the one lies as it were beyond, the other within the range of our natural domestic pleasures' ${ }^{62}$ While Italian performances might be admired, they must always remain far from the secure moral safety of "natural domestic pleasures'. Although not without resonance for attitudes towards male singers, this comparison between English musical restraint and domestic virtue carried particular significance for commentators writing about female singers in the music periodicals. As reports of the singing of Stephens and Travis suggest, in response to such attitudes among critics many English female singers appear to have felt it wiser to adopt the emotional 
restraint associated with feminine domestic propriety than the passionate self-expression of the musical artist.

By the late 1830s, however, the Musical World had taken the place of the defunct $Q M M R$ and Harmonicon as the leading music periodical of the day. In a parallel shift, the concern to reconcile English female singers' performances with domestic qualities, sometimes present in reviews in the $Q M M R$, was replaced by a growing impatience among at least some of the Musical World's contributors with English female singers' tendency to let concerns about propriety and emotional reserve stifle their creativity and self-expression as artists. The editor of the Musical World, for instance, in the same article in which he rejoiced in the transformation of English female singers from 'flippant dolls' to 'serious artists', went on to criticize the prim emotional restraint that held back English singers from fully realising their artistic potential:

English girls know more of $6 / 5$ and $9 / 4$ than of the dramatic method of being handsomely encircled in the arms of a lover; what "looks and tones,"... such a situation demands; what language should be addressed to a tyrannical father or a faithless inamorato - in fact the whole circle of passion, which far more instructs the human heart in expression that either $6 / 5$ or $9 / 4$, is known to them only by theory... The frigid, formal, perpetually conscious state of mere concertsinging, leaves three parts of the natural feeling in a state of hopeless torpidity. ${ }^{63}$

The demands of the new artistry - to express, for instance, the passions of the lover, the oppressed daughter or the betrayed spouse - clearly did not sit well with the idea that English female singers' performances should draw upon the restrained and chaste emotional experiences expected of women in the context of normal domestic felicity. As long 
as approaches to professional female singers were framed with reference to codes of appropriate domestic feminine behaviour, English female singers would remain, according to this reviewer, 'frigid, formal [and] perpetually conscious', unable to fulfil the new expectations of the musical artist as the communicator of all the 'fire and enthusiasm' of dramatic emotion. In part, the more forthright condemnatory tone of this passage stems from the fact that it was written in the Musical World, a periodical which Leanne Langley has argued had a readership primarily composed of the music profession, rather than the mixture of professionals and middle- and upper-class amateurs typical of the readership of periodicals like the $Q M M R .{ }^{64}$ It could therefore adopt a more rigorously professional outlook which necessarily distanced it from anxieties about the relationship between female professional musicians and gender codes. The editor's comments were also clearly motivated by a frustration at the absence of an English tradition of high opera and a desire to see one develop. Yet they also reflect a slow evolution in thinking about female singers as professional artists within the specialist music press by the 1840s, which replaced the ambivalence expressed by earlier writers in periodicals such as the $Q M M R$ with a more forthright declaration of the compatibility of femininity and expressive musical artistry in the new mould, or even more radically, the articulation of the irrelevance of traditional codes of feminine behaviour to critical approaches to female singers altogether.

\section{IV}

Despite some persistent reservations, therefore, writers in the specialist music press in the first half of the nineteenth century increasingly advanced the case for viewing female singers as professional 'serious artists'. Looking beyond the specialist press, however, it is clear that not every commentator on the musical world thought in this way, reflecting wider 
divergences in opinion among different types of audiences within the musical public. One way of assessing how influential the new ideas about female singers were is by examining a simple, but revealing, question: how important did various writers think the visual aspects of performance - particularly physical attractiveness - were when assessing and reporting on female singers? If professional musical performance was defined, as the specialist writers advocated it should be, as the communication of powerful interior emotion in a deeply serious and meaningful manner, then the attractiveness of the performer was of minimal importance. The skill with which the voice was manipulated to express emotion should be the focus of critical interest. If, on the other hand, female performance in particular was perceived as simply the enjoyment of a beautiful feminine object, then both the aural and visual qualities of that object were of relevance to the reviewer. Assessing a female singer on her physical attractiveness, at the expense of evaluating her vocal technique, training, musical stylistic choices, and talent, implicitly undermined her status as a professional artist. Consequently, the way in which various commentators from different sections of the press commented on the importance of the body and the physical attractiveness of singers discloses much about their conceptions of and attitudes towards female professionalism and artistry.

The physical attributes of singers were certainly not ignored by writers in the specialist press, but such discussion was framed with clear reference to the use of the body, and particularly the expression of emotion in the face and gestures, as an enhancer of the drama of musical performance, rather than simply as desirable or attractive. As Richard Mackenzie Bacon explained in the QMMR: 'How much of CATALANI's fascination is derived from her most exquisite indescribable accompaniments of face and gesture? No one can look upon MADAME RONZI DE BEGNIS without the instantaneous perception that her features and 
even her slightest movements present a complete index, graduating and determining the feeling by which she is influenced and excited.' ${ }^{65}$

This sense of the body as a 'complete index' of feeling is also present in Bacon's review of Rosamunda Pisaroni, who was so unattractive he declared: 'Look at her, and you exclaim, this woman can have no feeling.' Nevertheless, Bacon continues: 'She will not have sung six notes before it is perceptible that she is all sensibility - that she is a model of devotion to her art, and tremblingly alive to every breathing of passionate expression.' ${ }^{66}$ Audiences, according to Bacon, were not there simply to enjoy the visual and aural beauty of a singer's performance, but instead to feel the passions of the music, captured by the composer and expressed primarily through the sound alone that the singer produced. The absence of physical beauty, moreover, was not to be considered a bar to effective musical performance which, as in the case of Pisaroni, could be achieved through aural effects alone. ${ }^{67}$

Elsewhere in the press, however, assessing the physical attributes of singers remained paramount. A critic in The Drama: or, Theatrical Pocket Magazine in 1821 wrote of Catherine Stephens as 'certainly not regularly beautiful, but her fine eyes, the pleasing expression of her countenance, the natural elegance and unaffected modesty of her deportment, and her air of perfect simplicity, form an admirable introduction to her exertions as a singer, and excite the most intense interest of the beholders' ${ }^{68}$ Similarly, one commentator in The British Stage and Literary Cabinet in 1817 wrote of her: 'In person Miss Stephens is extremely pleasing. Her countenance, if not beautiful, irresistibly commands the regard and admiration of the spectator by its placid and good-tempered expression. These feelings are inexpressibly strengthened by the evident diffidence which pervades all she says and does'. ${ }^{69}$ The importance of Stephens's visual impression on her audience is 
underlined by these comments. Furthermore, it is particularly noteworthy that such impressions were perceived to be 'inexpressibly strengthened' by her 'diffidence' and 'unaffected modesty', equally evident to the viewer in her 'deportment'. For these writers, female musical performance was essentially a visually-pleasing display of feminine beauty, grace, and propriety, rather than an aurally-focused transfer of emotion through sound by a professionally trained, expressive artist.

In some writing, it was clear that the physical attractions of the performer were viewed as equally, if not more, important in securing their success with the London public. Anticipating the arrival in London of Henrietta Sontag, a German soprano whose beauty had been widely reported throughout Europe, one writer in the Athenaeum wondered whether: 'should we escape the fascination of [her] voice... yet shall we not yield to the charms of bright and playful eyes, of lips that rival the rose-bud, an angel's countenance, and a figure modelled after the Graces', demonstrating the power such physical attractions were thought to possess over contemporary audiences. ${ }^{70}$ It is important to remember that both Stephens and Sontag were stage- as well as concert-singers, a career path which undoubtedly rendered physical attributes of greater importance than was the case with those who specialized only in concert performance. Nevertheless, there is a clear difference between the style of commentary on the body in relation to dramatic performance by female singers in specialist periodicals and that of the general press. Whereas Bacon had argued for and analysed the body's use as a 'complete index' of feeling and an aid to expressive performance, the comments examined above imply an enjoyment of the visual beauties of female singers for their own sakes.

Writers in the specialist press were increasingly severely critical of audiences who continued to view singers in this light, thereby further indicating this divergence in styles of 
appraisal of female performance. One satire of fashionable audiences in the Musical World in 1836 mockingly advised that 'Ladies should never fail to take particular notice of the female singers' dress; and when they disapprove of them, they should boldly and loudly say so; and should their countenances not please them, there is no law against their saying in an audible manner, "what a fright!" "what a figure!" “I am sure I shall not like her singing, she is so ugly," \&c. \&c. ${ }^{\prime 71}$ Intriguingly, the worst culprits for an excessively visual appreciation of singers in this passage are female rather than male, though it seems unlikely that the Musical World satirist intended to imply that male viewers were any less visually-oriented than their female companions. Rather, this gendering of the visual mode of evaluating female singers as a feminine trait is a further sign of its dismissal by music critics as silly, superficial, and inferior to the masculine rigour of their purely aural judgements.

By the 1840s, contrasting approaches to the physical qualities of female singers was one of the key dividing lines between different groups of musical commentators and played a crucial part in campaigns for a new, more 'professional' style of music criticism. In 1844, James William Davison, editor of both the Musical World and the Musical Examiner, launched a wide-ranging attack on the critical style of Charles Gruneison, the music critic of the Morning Post (whom Davison, following Punch magazine, nicknamed 'Jenkins').72 Significantly, prominent among Davison's criticisms of this 'Amateur Critic' was a condemnation of his tendency to dwell on 'the persons and attire of female artists instead of their talent'. ${ }^{73}$ This was not an accusation without grounds: in a review for the Post, for instance, Gruneison wrote of the 'debutante' Miss Birch that she 'has la beauté du diable - la jeunesse, but she has also a fine organ to accompany her physique', her musical skills evidently playing a secondary 'accompanying' role to her physical attributes. ${ }^{74}$ Disgusted by the 'evident pleasure' Gruneison took 'in allusions of this nature', Davison complained: 
He is for ever at the person, or the dress, or the legs, or something of the kind, of the singers and dancers whom he criticises. In the unfortunate Post, he had a violent diatribe against a middle-aged lady, for singing in public with a bare neck; - she was (for Jenkins) trop decollettée! ${ }^{75}$

In Davison's opinion, Gruneison's expectation that all female singers must be young nubile nymphs, not wrinkled or fat, embodied a flawed approach to music criticism and by extension to the purpose of female musical performance. In exasperation, Davison asked: 'Why not, then, Jenkins, leave the necks, and legs, and dresses of the artistes (phrase de Jenkins) to take care of themselves, and try to say something about their talents as performers, whatever they may chance to be?'76

For Davison, and other critics writing in specialist music periodicals, Gruneison's critical failings were an insidious example of a wider trend to be found in the mainstream newspapers' musical columns. 'Jenkins is a type', Davison wrote, '- a great moral principle' typical of the 'mass of abomination, that constitutes the soi-disant criticisms' of the nonspecialist press. ${ }^{77}$ This style of newspaper criticism was continually mocked for its attitude towards female singers (among a range of other faults). In 1847, the Musical World sardonically published made-up reviews of the debut of the contralto Signora Vietti, supposedly taken from the Morning Chronicle and the Morning Post, which were designed to demonstrate their misplaced critical priorities. 'There are three grand requisites for a female singer in England,' the Morning Post's critic was supposed to have written, 'The first is face, the second figure, and the third is dramatic and vocal desiderata.' The review, which mostly concentrated on such topics as the 'beautiful rounded shoulders' of the 'remarkably handsome' Vietti, offered only a brief and deliberately absurd assessment of the singer's 
vocal skills: 'She not only sings from her mouth but the voice seems to come from all parts of her countenance, scintillating from her brow, beaming from her eyes, breathing from her nose, and melting from her lips. ${ }^{78}$ The incapability of these critics to think in anything other than visual terms was pointedly underlined.

Satirising those who commented on the physical attractiveness of female singers and focusing in their own reviews on their talent, professionalism, and artistry was an important part of a wider attempt by Davison and other critics in the specialist press to distinguish their more serious critical approach from the 'soi-disant criticism' of 'amateurs' like Gruneison and his colleagues. For Davison, music criticism was not about a singer's beauty or the dress she wore, but a technical evaluation of a complex skill requiring extensive knowledge and refined critical judgement. Nevertheless, Davison's frustration at the 'mass of abomination' that filled the newspapers reveals his own sense of the restricted sphere of influence of his more 'professional' critical style. With greatly inferior circulation figures to their rivals in the morning papers, the outlook of critics like Davison remained a minority viewpoint.

\section{V}

During the first half of the nineteenth century, it became possible to think of female singers as fully professional artists, and as a legitimate, respectable presence in public life, at least within the pages of a newly-emerging specialist music press. In contrast to the views of Hannah More or Sarah Stickney Ellis, writers in these specialist periodicals argued that the public professionalism and artistry of female singers should not be a cause for disquiet or suspicion. Instead, such women should be celebrated for their contribution to raising musical performance standards through their pursuit of professional and artistic ideals 
highly valued within the specialist press, such as careful training, highly-developed technique, and emotional expression. Furthermore, changing attitudes in the music press towards female singers were intricately connected to the desire of these music journalists to render music criticism a more professional, intellectual, and serious endeavour.

While this was an important development, it by no means represented a complete or sudden shift in attitudes. As has been shown, anxieties persisted, even in the specialist music press, about how far English female singers should pursue artistic self-expression, while outside of the music periodicals professional female singers were evaluated with much less regard to professional or artistic ideals. Female musical professionalism and artistry remained ambivalent and contested concepts right through this period and beyond.

Yet the new voices emerging in these debates remain significant and offer vital insights into the development of ideas of female professionalism and artistry in the nineteenth century. In contrast to the views of Ellen Jordan, who suggests that the religiously-inspired challenge mounted by writers such as Hannah More to narrow interpretations of women's domestic role lay behind the expansion in women's work as professional artists and musicians, ${ }^{79}$ this article has sought to demonstrate the incompatibility of the views of More and others with the professional ideals that animated the specialist musical press's approach to female singers. Indeed, the attitudes of writers in the specialist periodicals towards female singers had much more in common with the liberal social and economic philosophy, and its emphasis on skills and merit, that inspired the feminists who campaigned for women's employment opportunities after $1850 .{ }^{80}$ Admittedly, the gender-specific and inherently non-domestic nature of professional female singing made it an unusual case, but the changing attitudes towards female singers in the specialist press 
nonetheless represent strikingly early and bold iterations of ideas that would prove of vital importance to the later women's movement.

This raises the crucial question of whether and in what ways the lifestyles, work, and representations of female singers influenced some of the more well-studied later examples of women's pursuit of professional and artistic careers, and the women's movement more generally. It is surely significant, for instance, that the life of the professional female singer became symbolic of female independence in later nineteenth-century fiction, perhaps most clearly in George Eliot's Daniel Deronda (1876). ${ }^{81}$ Exploring these links between female singers and other forms of women's professional, artistic, and political activities lies beyond the scope of this article, but it remains an important avenue for future research. Building on the findings presented here, such work would further uncover the important but hitherto neglected role of the female singer in the formation and advocacy of ideas of female professionalism and artistry in nineteenth-century Britain.

Worcester College, Oxford, OX12HB david.kennerley@history.ox.ac.uk

*I am grateful to the AHRC for funding the research upon which this article is based. I would also like to thank Bob Harris, Kathryn Gleadle, and the editors and anonymous reviewers of the Historical Journal for their comments on earlier drafts of this article.

${ }^{1}$ See Tim Blanning, The triumph of music: composers, musicians and their audiences, 1700 to the present (London, 2008), ch. 1; Simon McVeigh, “"An Audience for High-Class Music”: concert promoters and entrepreneurs in latenineteenth-century London' in William Weber, ed., The musician as entrepreneur, 1700-1914: managers, charlatans, and idealists (Bloomington, IN, 2004), pp. 166-77.

2 See Cyril Ehrlich, The music profession in Britain since the eighteenth century: a social history (Oxford, 1985); Deborah Rohr, The careers of British musicians, 1750-1850: a profession of artisans (Cambridge, 2001).

\footnotetext{
${ }^{3}$ Margaret Homans, Women writers and poetic identity: Dorothy Wordsworth, Emily Brontë and Emily Dickinson (Princeton, 1980), pp. 13-40; Pamela Gerrish Nunn, Victorian women artists (London, 1987), pp. 15-26; Christine
} 
Battersby, Gender and genius: towards a feminist aesthetics (London, 1989), especially pp. 3-6 and ch. 4; Nancy B. Reich, 'Women as musicians: a question of class' in Ruth A. Solie, ed., Musicology and difference: gender and sexuality in music scholarship (Berkeley, CA, 1993), pp. 133-4.

${ }^{4}$ Leonore Davidoff and Catherine Hall, Family fortunes: men and women of the English middle class, 1780-1850 (London, 1987), especially part one.

${ }^{5}$ Penelope J. Corfield, Power and the professions in Britain, 1700-1850 (London, 1995), pp. 33-6, 188 and 213.

${ }^{6}$ Christina de Bellaigue, 'The development of teaching as a profession for women before 1870', Historical Journal, 44 (2001), pp. 963-88; Barbara Onslow, Women of the press in nineteenth-century Britain (Basingstoke, 2000), especially ch. 2; Linda M. Lewis, Germaine de Staël, George Sand, and the Victorian woman artist (Columbia, MO, 2003), esp. ch. 2; Deborah Cherry, Painting women: Victorian women artists (London, 1993), pp. 9-10 and 78-86. ${ }^{7}$ Sara M. Dodd, 'Art education for women in the 1860s: a decade of debate' in Clarissa Campbell Orr, ed., Women in the Victorian art world (Manchester, 1995), pp. 189-90, 195.

8 Paula Gillett, Musical women in England, 1870-1914: “Encroaching on All Man's Privileges" (Basingstoke, 2000), pp. $23-5$.

${ }^{9}$ Deborah Cherry, 'Women artists and the politics of feminism, 1850-1900' and Pam Hirsch, 'Barbara Leigh Smith Bodichon: artist and activist' in Campbell Orr, ed., Women in the Victorian art world, pp. 49-69 and 167-86.

${ }^{10}$ Patricia Zakreski, Representing female artistic labour, 1848-1890: refining work for the middle-class woman (Aldershot, 2006), pp. 15, 185-7.

${ }^{11}$ Ellen Jordan, The women's movement and women's employment in nineteenth-century Britain (London, 1999), ch. 5 and pp. 112-14.

${ }^{12}$ Jane Rendall, The origins of modern feminism: women in Britain, France and the United States, 1780-1860

(Basingstoke, 1985); Kathryn Gleadle, The early feminists: radical unitarians and the emergence of the women's rights movement, 1831-51 (Basingstoke, 1995).

${ }^{13}$ De Bellaigue, ‘Teaching as a profession for women', pp. 965-6, 968-9, 978-9; Eva Gamarnikow, ‘Nurse or woman: gender and professionalism in reformed nursing, 1860-1923' in Pat Holden and Jenny Littlewood, eds., Anthropology and nursing (London, 1991), pp. 110-11, 123-9.

${ }^{14}$ Linda H. Peterson, Traditions of Victorian women's autobiography: the poetics and politics of life writing (Charlottesville, VA, 1999), pp. 155-6. 
${ }^{15}$ Felicity Nussbaum, Rival queens: actresses, performance and the eighteenth-century British theater (Philadelphia, PA, 2010), pp. 280-4; Gill Perry, 'Ambiguity and desire: metaphors of sexuality in late eighteenth-century representations of the actress' in Robyn Asleson, ed., Notorious muse: the actress in British art and culture, 1776-1812 (New Haven, CT, 2003), pp. 57-62 and 66.

${ }^{16}$ Rohr, The careers of British musicians, esp. ch. 10.

${ }^{17}$ De Bellaigue, 'Teaching as a profession for women', p. 965. De Bellaigue cites Magali Sarfatti Larson, The rise of professionalism: a sociological analysis (Berkeley, CA, 1977) and Rolf Torstendahl, ‘Essential properties, strategic aims and historical development: three approaches to theories of professionalism' in Michael Burrage and Rolf Torstendahl, eds., Professions in theory and history: rethinking the study of the professions (London, 1990), pp. 44-61. ${ }^{18}$ Frederick Corder, A history of the Royal Academy of Music from 1822 to 1922 (London, 1922), pp. 2-3, 8-11; Rohr, The careers of British musicians, pp. 84-5.

${ }^{19}$ Deborah Rohr, ‘Women and the music profession in Victorian England: The Royal Society of Female Musicians, 1839-1866', Journal of Musicological Research, 18 (1999), pp. 307-46.

${ }^{20}$ Some of this work has been undertaken elsewhere: David Kennerley, "“Flippant dolls" and "serious artists": professional female singers in Britain, c.1760-1850', (D.Phil. thesis, University of Oxford, 2014), chs. 3-5.

${ }^{21}$ Leanne Langley, 'The English musical journal in the early nineteenth century', (Ph.D. dissertation, University of North Carolina at Chapel Hill, 1983), pp. xx-xxi, 18-31 and Leanne Langley, 'The musical press in nineteenthcentury England', Notes, 46 (1990), pp. 583-92, esp. pp. 587-8, especially note 16.

${ }^{22}$ L[eanne]. L[angley]., 'Musical press' in Iain McCalman, ed., An Oxford companion to the Romantic age: British culture, 1776-1832 (Oxford, 1999), p. 615.

${ }^{23}$ Langley, 'The English musical journal', pp. xx-xxi, 51, 219-20.

${ }^{24}$ Ibid., pp. 169, 171-2, 185-6 and 190.

${ }^{25}$ Langley, 'The musical press in nineteenth-century England', pp. 585-7; Leanne Langley, 'Victorian periodicals and the arts: music' in Rosemary VanArsdel and J. Don Vann, eds., Victorian Periodicals and Victorian Society (Aldershot, 1994), p. 103.

${ }^{26}$ Bacon wrote a regular column entitled 'Report on Music' for The London Magazine from 1820 to 1825, Ayrton contributed to the Morning Chronicle between 1813 and 1826 and The Examiner from 1837 to 1851, and Davison held the post of music critic at The Times between 1846 and 1879, as well as writing for several other newspapers. 
${ }^{27}$ See, for example, Audi Alteram Partem, 'To the editor', QMMR, 7/27 (1825), pp. 288-92; 'A hint to singers', Musical World, 1/3 (1 Apr. 1836), pp. 41-44; and 'On musical expression', Harmonicon, 2/19 (July 1824), pp. $128-29$. ${ }^{28}$ Audi Alteram Partem, 'To the editor', p. 289.

${ }^{29}$ Vetus, 'To the editor', QMMR, 4/13 (1822), p. 1.

30 'On the differences in the singing of professors and amateurs', $Q M M R, 6 / 23$ (1824), pp. 318-23.

${ }^{31}$ Michèle Cohen, 'Language and meaning in a documentary source: girls' curriculum from the late eighteenth century to the Schools Inquiry Commission, 1868', History of Education, 34 (2005), pp. 77-93, esp. pp. 80, 87-92.

32 Ibid., pp. 89-92; Richard Leppert, Music and image: domesticity, ideology and socio-cultural formation in eighteenthcentury England (Cambridge, 1988), pp. 28-45, 147-68; Kennerley, 'Professional female singers', ch. 1.

${ }^{33}$ Hannah More, Essays on various subjects, principally designed for young ladies (London, 1777), p. 135. Five new editions were published between 1810 and 1850 .

${ }^{34}$ Mrs. [Hester] Chapone, Letters on the improvement of the mind, addressed to a young lady (2 vols., London, 1773), II 43-4. Seventeen new editions appeared between 1810 and 1850.

${ }^{35}$ Erasmus Darwin, A plan for the conduct of female education, in boarding schools (Derby, 1797), p. 12.

${ }^{36}$ Mrs. [Sarah Stickney] Ellis, The daughters of England, their position in society, character E responsibilities (London, 1842), pp. 106-7.

37 Ibid., pp. 233-4.

${ }^{38}$ Ibid., p. 238.

${ }^{39}$ Ibid., p. 244.

${ }^{40}$ As is pointed out by Jay Mechling, 'Advice to historians on advice to mothers', Journal of Social History, 9 (1975), pp. 44-63.

${ }^{41}$ Jordan, Women's employment, ch. 5 (esp. pp. 92-98), pp. 112-14 and p. 147.

${ }^{42}$ Vetus, 'To the editor', QMMR, 1/4 (1818), p. 421.

43 'Miscellaneous', Musical Examiner, 2/74 (30 Mar. 1844), p. 502.

44 ‘The King's Theatre', QMMR, 10/38 (1828), pp. 269-70.

45 [Editorial], Musical World, 12/95 (24 Oct. 1839), p. 398.

46 'Sketch of the state of music in London, June 1821', QMMR, 3/11 (1821), p. 385. 
${ }^{47}$ For other examples, see: 'Madame Mara nee [sic.] Schmelling', QMMR, 1/2 (1818), pp. 171-2; 'Sketch of the state of music in London', QMMR, 9/33 (1827), p. 52; 'Strand theatre', The Musical Magazine, 1/3 (Mar. 1835), p. 46; 'Choral Harmonic Society', The Musical Journal, 1/5 (4 Feb. 1840), pp. 74-75; 'Sacred Harmonic Society', The Musical Journal, 1/14 (7 Apr. 1840), p. 222.

48 [Editorial], Musical World, 11/65 (28 Mar. 1839), p. 189.

${ }^{49}$ Egerton Webbe, 'Our musical wants. No. III', Musical World, 6/73 (4 Aug. 1837), p. 114.

${ }^{50}$ Rohr, The careers of British musicians, pp. 109-12.

51 'English' and 'Italian' are here used (following the conventions of contemporary debate) to refer to all singers from the British Isles and all foreign singers at the Italian opera, respectively.

${ }^{52}$ Anglicus, 'On the differences between Italian and English manner of singing. To the editor', $Q M M R, 4 / 16$ (1822), p. 401.

${ }^{53}$ See, for instance: Analysis, 'On style. To the editor', $Q M M R, 3 / 12$ (1821), pp. 411-12; An Englishman, 'Foreign instruction \& English judgment. To the editor', QMMR, 8/32 (1826), pp. 409-11.

54 'Miss Stephens', QMMR, 3/9 (1821), pp. 60-1.

${ }^{55}$ Ibid., p. 62.

${ }^{56}$ See, for instance: 'Madame Pasta', QMMR, 6/22 (1824) pp. 217-18; 'Sketch of the state of music in London, 1828', QMMR, 10/37 (1828), footnote to p. 70.

57 'Miss Travis', QMMR, 1/4 (1818), p. 471.

${ }^{58}$ See, for instance: 'Madame Camporese', $Q M M R, 3 / 12$ (1821), p. 459; 'Mademoiselle Sontag', QMMR, 9/36 (1827) pp. 483-4; Anglicus, 'To the editor', p. 402.

59 ‘Miss Paton', QMMR, 5/18 (1823), p. 192.

${ }^{60}$ Anglicus, 'To the editor', p. 402.

${ }^{61}$ Mediator, 'Gran gusto. To the editor', QMMR, 7/27 (1825), pp. 286-7.

${ }^{62}$ Anglicus, 'To the editor', p. 407.

${ }^{63}$ [Editorial], Musical World, 11/65 (28 Mar. 1839), p. 191. 6/5 and 9/4 are musical time signatures; the first is theoretically impossible and the second is very unusual.

${ }^{64}$ Langley, 'Musical press', p. 588.

65 ‘Miss Paton', QMMR, 5/18 (1823), p. 192. 
66 'The King's Theatre', p. 269.

${ }^{67}$ The advocacy of female violin-playing in the specialist periodicals was even more striking in this regard.

Traditionally, the posture required for violin-playing was considered too ungraceful for women, but the Musical World defended female violinists by stating: 'The grace which belongs to violin-playing is audible rather than visible, residing in the effect more than in the means; nor ought we to be such cormorants of pleasure, as to demand that the person who is filling our ears with rapture shall, at the same time, be enchanting to the utmost our eyes' ('Female performers on the violin', Musical World, 12/72 (16 May 1839), pp. 34-5). See also 'Mara, Billington and Catalani', QMMR, 1/2 (1818) footnote to p. 171.

68 'Miss Stephens', The Drama: or, Theatrical Pocket Magazine, 1/3 (July 1821), pp. 108-9.

69 'Miss Stephens', The British Stage and Literary Cabinet, 1/1 (Jan. 1817), p. 4.

70 'History of Henrietta Sontag', The Athenaeum, 24 (15 Apr. 1828), p. 375.

${ }^{71} \mathrm{D}$ b , ‘Concert audiences', Musical World, 4/41 (23 Dec. 1836), p. 13.

${ }^{72}$ See Punch, or the London Charivari, 4 (1843), pp. 126, 146, 156.

${ }^{73}$ J. W. D. [James William Davison], 'An amateur critic', Musical World, 19/50 (12 Dec. 1844), p. 404.

${ }^{74}$ Morning Post, 3 Apr. 1844.

75 'Jenkins again', Musical Examiner, 2/92 (3 Aug. 1844), p. 711.

${ }^{76}$ Ibid., p. 712.

77 'Miscellaneous', Musical World, 19/33 (15 Aug. 1844), p. 272.

78 'Anticipatory criticisms on the debut of Signora Vietti at Her Majesty's Theatre in two morning papers', Musical World, 22/16 (17 Apr. 1847), p. 247.

${ }^{79}$ Jordan, Women's employment, ch. 5, esp. pp. 92-98; pp. 112-14 and 147.

${ }^{80}$ Ibid., ch. 8.

${ }^{81}$ George Eliot, Daniel Deronda, ed. Graham Handley (Oxford, 1984), especially chs. xxiii, li and liii. For discussion of Eliot's depiction of female singers, see Susan Rutherford, 'The voice of freedom: images of the prima donna' in Viv Gardner and Susan Rutherford, eds., The New Woman and her sisters: feminism and the theatre 1850-1914 (New York, 1992), pp. 100-3. 